YEARBOOK

of ANTITRUST

and REGULATORY

STUDIES

www.yars.wz.uw.edu.pl
Peer-reviewed scientific periodical, focusing on legal and economic issues of antitrust and regulation. Creative Commons Attribution-No Derivative Works 3.0 Poland License.

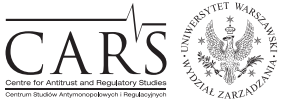

Centre for Antitrust and Regulatory Studies, University of Warsaw, Faculty of Management www.cars.wZ.uw.edu.pl

\title{
A Note on 2015 Developments in Polish Competition Law: Is it Really a Drive Towards the European Model?
}

\author{
by
}

\section{Anna Piszcz}

\section{CONTENTS}

I. Introduction

II. Remedies in infringement decisions

III. Fines

IV. Leniency program

V. Settlements

VI. Concentrations between undertakings

VII. Conclusions

\section{Abstract}

Modern Polish competition law has become highly regulated and codified over the twenty five years of its existence and this article will provide readers with information relating to its recent developments of 2015. Separate subsections present a review of provisions on remedies in infringement decisions as well as settlements. A considerable part of this paper is designed to outline the peculiarities that characterize Poland's new provisions on fines. Further on, the paper introduces readers to newest trends in the area of concentration control between undertakings. In addition, an assessment of recent developments and suggestions for a further development of Polish competition law are reviewed in the EU context. The conscious intention of the author is to analyse whether the EU competition law pattern, often regarded as a model for Member States, has been used to develop

* Dr. Hab., Professor at the University of Białystok, Faculty of Law, Department of Public Economic Law; legal advisor; piszcz@uwb.edu.pl. Article received: 27 October 2016; accepted: 7 November 2016.

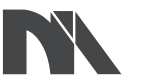

\section{Ministry of Science and Higher Education}

Republic of Poland
The creation of the English-language version of these publications is financed in the framework of contract No. 768/P-DUN/2016 by the Ministry of Science and Higher Education committed to activities aimed
at the promotion of education. 
Polish competition law. Has the latter been amended to look more, or less like EU competition law? Has Polish competition law shown the capacity to absorb the best elements of EU competition law into itself? How is the outcome aligned with the declared direction of these amendments?

\section{Résumé}

Le droit de la concurrence polonais moderne est devenu très réglementé et codifié au cours des vingt-cinq années de son existence et cet article fournit aux lecteurs des informations relatives à ses développements récents de 2015. Des sous-sections séparées présentent un examen des dispositions concernant les recours dans les décisions d'infraction ainsi que dans la procédure de transaction. Une grande partie partie de cet article vise à présenter les particularités qui caractérisent des nouvelles dispositions de la loi polonaise concernant les sanctions. Ensuite, l'article présente aux lecteurs les tendances les plus récentes dans le domaine du contrôle des concentrations entre entreprises. De plus, une évaluation des développements récents et la proposition des reformes possibles du droit polonais de la concurrence sont examinées dans le contexte de l'Union européenne. Lidée d'auteur est d'analyser si le modèle européen du droit de la concurrence, souvent considéré comme un modèle pour les Etats Membres, a été utilisé pour développer le droit polonais de la concurrence. Est-ce que le droit polonais de la concurrence a été modifié afin de rassembler le droit de l'Union européenne ou non? Est-ce que le droit polonais de la concurrence a démontré sa capacité à intégrer les meilleurs éléments du droit européen de la concurrence? Comment les résultats des modifications de la loi polonaise sur la concurrence correspondent avec les objectifs des changements?

Key words: remedies; settlements; fines; individuals; leniency plus; control of concentrations.

JEL: K21

\section{Introduction}

Over a quarter of a century has passed since the establishment of the first modern Polish Antimonopoly Act (1990) as well as the creation of the Office for Competition and Consumer Protection - originally called the Antimonopoly Office. For the first time, at least to such an extent, an institutional focus for addressing matters concerning competition policy was provided ${ }^{1}$. The 1990

1 Under the 1987 Antimonopoly Act, the Finance Minister was responsible for the protection of competition. 
Act prohibited certain types of agreements and practices, including certain practices of dominant undertakings and undertakings in a monopolistic position, among other things, the so-called abuse of a dominant position. Furthermore, it contained provisions on the control of concentrations between undertakings. In many respects, the provisions of the 1990 Act were dissimilar from those in the European Community.

On 16 December 1991, Poland signed the Association Agreement with the European Community. The pre-accession strategy placed a specific emphasis on the promotion of the progressive harmonization of Polish laws with the legal regime of the European Community, especially in the areas of competition law and state aid. As a result of painstaking work to draft a new Polish competition law, the Act on Competition and Consumer Protection was finally adopted on 15 December 2000 . The new law included substantive rules which resembled the legal rules contained in Articles 81 and 82 of the Treaty Establishing the European Community ${ }^{2}$. They were also approximated to Council Regulation (EEC) No. 4064/89 of 21 December 1989 on the control of concentrations between undertakings ${ }^{3}$, and Commission Notice on agreements of minor importance which do not fall within the meaning of Article 85(1) of the Treaty establishing the European Community ${ }^{4}$, a soft law document. The 2000 Act provided a legal basis for the de minimis exclusion and rule of reason exemptions with regard to competition restricting agreements. It also remodelled provisions on the control of concentrations, narrowing their scope and attempting to make them a bit more "Europeanized". The 2000 Act was amended several times. Worth mentioning here, in particular, are important amendments which came into force on 1 May 2004, the date of Poland's accession to the European Union. The amendments adopted in 2004 were an attempt to bring the Act in line with Council Regulation (EC) No. $1 / 2003^{5}$ and certain EU soft laws (including the rules resulting from the establishment of

2 Rome Treaty of 1957. Currently Articles 101 and 102 of the Treaty on the Functioning of the European Union (hereinafter, TFEU).

3 OJ L 395, 30.12.1989, p. 1-12. It was replaced by the current Council Regulation (EC) No. 139/2004 of 20.01.2004 on the control of concentrations between undertakings, OJ L 24, 29.01.2004, p. 1-22 (hereinafter, Regulation 139/2004).

4 The Notice was published in OJ C 372, 9.12.1997, p. 13-15. It was replaced by Commission Notice on agreements of minor importance which do not appreciably restrict competition under Article 81(1) of the Treaty establishing the European Community (de minimis), OJ C 368, 22.12.2001, p. 13-15. Currently in force is Commission Notice on agreements of minor importance which do not appreciably restrict competition under Article 101(1) of the Treaty on the Functioning of the European Union (De Minimis Notice) (OJ C 291, 30.08.2014, p. 1-4).

5 Council Regulation (EC) No. 1/2003 of 16.12 .2002 on the implementation of the rules on competition laid down in Articles 81 and 82 of the Treaty, OJ L 1, 04.01.2003, p. 1-25 (hereinafter, Regulation 1/2003). 
the European Competition Network ${ }^{6}$ and the rules on the leniency program ${ }^{7}$ ). They extended the role of the competition authority to include the performance of functions and responsibilities expected of a national competition authority 8 within the meaning of Regulation 1/2003. Other than that, developments in three particular fields were evident: provisions on commitment decisions, interim measures and leniency program were introduced.

In 2007, the 2000 Act was replaced with the Act on Competition and Consumer Protection (16 February 2007) ${ }^{9}$, even though it was not, in fact, necessary to adopt a new Act due to the limited scope of the changes. However, Polish legislators opposed the idea of introducing further amendments to the 2000 Act. As a result, the (2007) Act was not materially amended until its recent general revision of 2015. It is worth noting, however, that the President of the Office for Competition and Consumer Protection, in Polish Prezes Urzędu Ochrony Konkurencji i Konsumentó $w^{10}$, has mirrored the approach of the European Commission and produced, under the (2007) Act, several acts of non-binding guidance on a wide range of issues - from methods of calculating fines to commitment proceedings.

After the Act was in operation for a sufficiently long time (about five years), necessary preparatory legislative activities were undertaken in 2012 by the government, represented by the UOKiK President. As a result, the Amendment Act of 10 June 2014 was produced ${ }^{11}$ two years later, which came into force on 18 January 2015. The changes made by the Amendment Act to the (2007) Act can be seen as conscious efforts to increase the effectiveness of competition law enforcement in Poland. It is true, however, that some of these shifts appear to be very far-reaching. The explanatory notes accompanying the draft Amendment Act (performing a largely justificatory function) state that several of its new legal concepts reflect lessons learned from the experiences of other jurisdictions, including the EU. It is fair to say that the above statement is likely to have been made in order to avoid the accusation that some of the amendments perhaps go too far in an attempt to protect competition to the detriment of the freedoms of undertakings.

6 Commission Notice on cooperation within the Network of Competition Authorities, OJ C 101, 27.04.2004, p. 43-53.

7 Commission notice on immunity from fines and reduction of fines in cartel cases, OJ C $45,19.02 .2002$, p. $3-5$. It was replaced by Commission Notice on immunity from fines and reduction of fines in cartel cases, OJ C 298, 8.12.2006, p. 17-22.

${ }^{8}$ Hereinafter, the NCA.

9 Consolidated text Journal of Laws of the Republic of Poland 2015, item 184 (hereinafter, the Act).

10 Hereinafter, the UOKiK President.

11 Journal of Laws of the Republic of Poland 2014 item 945 (hereinafter, the Amendment Act). 
It is worth noting here that whereas national substantive competition rules, modelled very closely on Articles 101 and 102 TFEU, are relatively convergent throughout the EU, considerable divergences exist in procedures and, in some cases, in fining powers ${ }^{12}$. The most common model of competition proceedings within the EU is the administrative model, where a single administrative authority investigates cases and takes enforcement decisions subject to judicial control. A minority of Member States operates a judicial model where, in essence, an administrative authority carries out the investigation and then brings the cases before a court, either for a decision on substance and on sanctions ${ }^{13}$, or in relation to the imposition of sanctions only ${ }^{14}$. National competition law systems deviate on important aspects such as fines, criminal sanctions, liability within groups of undertakings, liability of associations of undertakings, succession of undertakings, prescription periods and the standard of proof, as well as the power to impose structural remedies (Cseres, 2014, p. 53).

With this being noted, this article poses the research problem, apart from exploring the amendments of 2015, whether the Polish competition law system achieved a higher degree of convergence with EU competition law than before thanks to the reviewed Amendment Act. In light of the above, a question to be addressed is that of the scope of the amendments, covered in more detail later in this article. The Amendment Act contains a broad range of amendments to the Polish legislative framework for the protection of competition and consumers. They lead to wider questions surrounding the effectiveness of competition law enforcement. However, not all amendments of 2015 can receive the same level of attention (if any) in this paper. Minor, non-material changes as well as amendments to competition rules considered non-challenging in terms of convergence have been omitted. Their inclusion would considerably lengthen the article and make it less tractable. Moreover, the discussion of amendments introduced by the Amendment Act of 31 August 2015, which came into force as of 17 April $2016^{15}$, is outside the scope of this article, since they primarily concern consumer protection. This article attempts to shed light on changes made to those aspects of Polish competition law that remained the most divergent from EU law until now. They include: the power to impose remedies in infringement decisions, fines (including issues

12 See the Communication from the Commission to the European Parliament and the Council - Ten Years of Antitrust Enforcement under Regulation 1/2003: Achievements and Future Perspectives, $\operatorname{COM}(2014) 453$, p. 3.

13 Austria and Estonia operate this model in criminal proceedings; Ireland and Sweden - in cases involving the imposition of a fine.

14 Denmark, except for administrative fines, and Finland.

15 Journal of Laws of the Republic of Poland 2015 item 1634. 
such as settlements and the leniency program) and merger (concentration) control proceedings. Each of these amendments merits research attention. However, the focus of this paper is directed toward the most interesting ones from the convergence/divergence perspective. Although each section deals with a separate issue, when viewed from this perspective, none of them can be addressed in isolation, without consideration of the others.

It would be fair to assume that the amendments were based on input from Polish jurisprudence, but this was not the case. It should be emphasized first that the explanatory notes do not note the impact of jurisprudence. Second, although over one hundred judgments were adopted and published on the basis of the (2007) Act in the five years of its applicability, they appeared to pay little attention to EU law or jurisprudence as the sources of inspiration for the interpretation of Polish law or propositions de lege ferenda. Jurisprudence research conducted for the purposes of this article confirms, rather than disproves, that Polish courts discussed at some length issues relating to solutions subject to amendments presented in this paper. The time-frame for jurisprudence examination strictly adhered to the five-year period mentioned above, after which the government decided to proceed with the amendment process. The examination of jurisprudence covers various jurisdictional levels: the Regional Court of Warsaw - the Court of Competition and Consumer Protection (SOKiK), the Appellate Court of Warsaw (SA) and the Supreme Court (SN).

\section{Remedies in infringement decisions}

Until the Amendment Act, the Act did not provide for any behavioural or structural remedies when it comes to infringement decisions regarding anticompetitive practices (Article 10 of the Act). Polish jurisprudence for the relevant time-frame and jurisdictional levels has not offered any judicial opinion on the subject of this "lacuna" in Article 10 of the Act ${ }^{16}$. Although the explanatory notes accompanying the Amendment Act do not refer to EU law as a point of reference with respect to the newly introduced remedies, it is clear that the provisions of Article 7 sentences 2 and 3 of Regulation 1/2003,

16 It is, however, worth mentioning a SOKiK judgment (adopted before the time-frame of this jurisprudence examination and even before the adoption of the (2007) Act) where the court had emphasized that legal provisions only allowed the UOKiK President to require in an infringement decision that an infringement be brought to an end and not require an undertaking to act in a specified manner or apply structural remedies. See SOKiK judgment of 24.04.2002, XVII AmA 73/01. 
were intended (to some extent at least) to be a model for Poland. The assumptions behind the draft Amendment Act, published and submitted for public consultation in 2012, admitted this fact ${ }^{17}$. However, under the Act (after the amendments of 2015) the label of "remedies" or rather "means"18 is attached to means which in fact are regulated in a way suggesting not only a link between the Polish provisions and the EU model, but also divergences.

First of all, Polish provisions do not use phrases such as "behavioural remedies" and "structural remedies". There are two groups of remedies and each of them is now regulated by a specific paragraph in Article 10 of the Act paragraphs 4 and 5. The list of remedies mentioned in paragraph 4 is not exhaustive. It contains remedies such as the grant of a license, the grant of access to infrastructure, the obligation to supply a product or service to certain entities, the change of a contract ${ }^{19}$. It results from paragraph 4 that the first three remedies mentioned must be implemented on non-discriminatory terms. On the other hand, paragraph 5 exhaustively provides for remedies in the form of an obligation to delegate certain business activities (including business activities at different points in the distribution chain) to various members of the capital group or separate organizational units within the structure of the business.

The above-discussed provisions give priority to remedies of the first type. Remedies of the second type can only be imposed where remedies of the first type might prove to be either ineffective or effective, but more burdensome for the undertaking concerned than a remedy of the second type. These are circumstances similar to those specified in Regulation 1/2003. Moreover, remedies should be proportionate to the type and significance of the infringement committed as well as necessary to bring the infringement to an end or eliminate its effects (paragraph 6). Commentators would wish to see these provisions as associated with the EU model (Jurkowska-Gomułka, 2014, p. 546).

However, an important difference is manifested in the purposes of the remedies. The Commission may impose remedies on infringers in order to bring an infringement to an end. By contrast, the UOKiK President may impose remedies in order to cause the infringement to cease, or in order to eliminate its effects. Second, it is argued that under the Act it is impossible to distinguish behavioural remedies and structural remedies on the very basis of placing them in separate paragraphs, dissociated from each other with criteria

17 Polish version available at: www.uokik.gov.pl/download.php?plik=11761 (all Internet references in this article were last visited on 7 October 2016).

18 In Polish "remedies" are called środki zaradcze and "means" are called środki; the Amendment Act uses the second term.

19 However, prohibited agreements are null and void (Article 6 paragraph 2 of the Act). 
of effectiveness and burdensomeness. Remedies specified in paragraph 5 shall not necessarily be of structural nature as they shall not necessarily consist of changes in the structure of the business (Sroczyński, 2015b, p. XIII).

The explanatory notes accompanying the Amendment Act state that the introduction of a legal basis for remedies has been requested by undertakings. They allegedly used to report the need for detailed information from the UOKiK President on how to comply with infringement decisions because they had doubts about it and were afraid of sanctions for non-compliance. It is doubtful that such cases were frequent. Undertakings (or at least their lawyers) understand that remedies are intended to discipline rather than to support an infringer.

The introduction of the UOKiK President's power to impose remedies is, in the author's opinion, one of the most significant amendments contained in the Amendment Act. The latter brings about changes in the role of the NCA - from merely a policing role, to a more proactive role in the enforcement of competition law. From the UOKiK President's perspective, it can be argued that his new power to impose remedies can help improve the effectiveness of his decisions (Skoczny, 2015, p. 169; Kowalik-Bańczyk, 2014a, p. 706-707). There has never been a more comprehensive model of antitrust control in Poland than now when remedies exist. However, the first 18 months of the new provisions have not shown practical examples of the use of remedies. It remains to be seen whether the UOKiK President will follow the European Commission's approach with respect to the application of remedies.

The extent to which Polish provisions are inspired by similar provisions found in Regulation 1/2003 is far from being accidental. But, indeed, they deviate from the EU's original conceptualization of remedies. However, it is important to note that technically Poland left that group of Member States, which has NCAs with no power to impose any kind of remedies, either of a behavioural or structural nature (Finland, Slovakia) ${ }^{20}$. Unlike in those Member States where a competition authority may not impose structural remedies (Denmark, Sweden, Lithuania), the Polish NCA was granted full power to impose remedies. This shift should be considered correct, efficient and approximating Polish solutions to the level of competences of the European Commission.

20 ECN Working Group Cooperation Issues And Due Process, Decision-Making Powers Report, 31.10.2012, available at: www.ec.europa.eu/competition/ecn/decision_making_powers_ report_en.pdf, p. 11, 15. 


\section{Fines}

Before discussing amendments made to the provisions on fines, a related issue must be noted first. An important dimension of the enforcement of the prohibitions of anticompetitive practices in Poland is that statutory grounds for the initiation by the NCA of proceedings upon a complaint (upon request) ceased to exist after the adoption of the (2007) Act. Under the Act, the UOKiK President only commences proceedings - in which he imposes fines - on his own initiative. Hence, the status of a party to the proceedings is reserved to those to whom the infringement is, rightly or wrongly, attributed by the UOKiK President ${ }^{21}$. This seems to have been the cause, or one of the causes, of a gradual fall in the number of proceedings regarding anticompetitive practices conducted by the UOKiK President. The numbers hit an unprecedentedly low figure of 128 in 2011, compared to 361 in 2006 and 248 in 2007. At the same time, fines imposed on undertakings have risen dramatically from about PLN 171 million (approx. EUR 41.71 million) in 2007 to around PLN 325 million in 2011 (approx. EUR 79.27 million) 22. As such, a few years ago fines have become central to Polish ways of talking about deterrence for undertakings' participating in anticompetitive practices (for more, see: Piszcz, 2013, p. 324 et seq.; Molski, 2009, p. 73; a range of issues is debated here, among other things the nature of fines, criminal or noncriminal, in eg Król-Bogomilska, 2001, p. 184-202; here the emphasis is placed on fundamental rights in the debate surrounding competition law sanctions eg: Król-Bogomilska, 2012, p. 23-26; Doniec, 2015; see also Martyniszyn and Bernatt, 2015, p. 1023).

Prior to the Amendment Act, fines for anticompetitive practices could reach up to $10 \%$ of the party's revenue in its fiscal meaning. Following its adoption, they can now reach up to $10 \%$ of the party's turnover in its accountancy meaning. This has marked a shift to the European model. However, divergences still exist with regard to the principles of calculating fines, in particular the base used for calculating the basic amount of the fine and the method for taking into account gravity and duration of the infringement.

21 This difference found between the Polish procedure and the procedure before the Commission laid down in Regulation 1/2003 has not been addressed by the Amendment Act at all.

22 See: the UOKiK President's reports on activities; available at http://www.uokik.gov.pl/ reports_on_activities.php.

23 The authors say that "in the Polish cultural and procedural contexts criminalization of (only) hard-core horizontal agreements would bring about greater deterrence, giving at the same time the individuals concerned fully-fledged procedural guarantees". 
On the other hand, Polish periodic penalty payments of up to EUR 10,000 per day have always been crucially different from those imposed by the European Commission. The latter were designed to compel the addressee to comply with a decision. Polish periodic penalty payments may not only be imposed for the aforementioned purpose, but may also be used ex post, after the decision has already been complied with, in order to punish the addressee for delayed compliance. Before the Amendment Act, the delay in compliance was described with the Polish word zwtoka, which means (at least under private law) culpable delay. After the Amendment Act, there is no doubt that delay in compliance should be assessed by objective standards (the Polish word opóźnienie is used). The question of standards for the assessment of delay was canvassed extensively by Polish courts, which delivered several judgments on periodic penalty payments in the relevant time-frame. The prevailing opinion held in the vast majority of the analysed judgments was that for the purpose of applying such sanctions, the UOKiK President was directed, when assessing the conduct of a party as a professional, to prove a period of culpable, intentional or negligent delay ${ }^{24}$. However, in a minority of the judgments, courts supported the contradicting view that under public law, the Polish word zwtoka was a synonym of the word opóźnienie and it was sufficient to only apply objective standards ${ }^{25}$. The amendment was considered to address the problem of this divergent jurisprudence.

The amended provisions on fines show dissimilarities from EU law apparent in some other aspects also. At least in the EU, legal provisions do not seem preoccupied with the risks posed by situations where an undertaking has a low turnover. Such provisions have emerged in Poland after the adoption of the Amendment Act. It is fair to say that the change was not inspired by judicial input. The latter did not have an opportunity to argue the issue of the effectiveness of sanctions imposed on undertakings with a low turnover, since decisions imposing low fines are very seldom appealed by their addressees. However, the reason for the introduction of new provisions on this issue might be that the UOKiK President, who prepared the draft Amendment Act, knew perfectly well that a portion of his decisions could not include any fines for reason of a low turnover alone. This is so because a low fine

${ }^{24}$ See SN judgment of 11.08.2009, III SK 17/09; SA judgment of 29.09.2008, VI ACa 527/08; SOKiK judgment of 16.01.2008, XVII AmA 73/08; SOKiK judgment of 29.06.2010, XVII AmA 95/09; SA judgment of 3.04.2012, VI ACa 998/11; SOKiK judgment of 11.05.2011, XVII AmA 37/10; SA judgment of 30.11.2009, VI ACa 1039/09; SN judgment of 2.07.2009, III SK 10/09; SA judgment of 17.09.2008, VI ACa 344/08; SOKiK judgment of 30.10.2007, XVII AmA 62/06; SN judgment of 3.10.2013, III SK 51/12.

25 SA judgment of 17.05.2012, VI ACa 1428/11; SOKiK judgment of 3.10.2011, XVII AmA 8/10. 
would not be capable of performing its functions, and a higher fine would not be proportionate in the circumstances of the case ${ }^{26}$. The new provisions seem able to contribute to the effectiveness of Polish competition law, yet on the other hand they increase the level of divergence between the Polish legal system and that of the EU. If an undertaking had a low turnover or no turnover at all in the preceding business year, the UOKiK President may impose thereon a fine based on the average turnover achieved over the three preceding business years. If also such average turnover is low, a fine may be up to EUR 10,000. The upper limit of low turnover is defined as EUR 100,000 (Article 106 paragraphs 5 and 6 of the Act).

One of the features of the current Polish legal framework (once again not inspired by jurisprudence) is that managers are beginning to think of themselves as subjects of control by the UOKiK President; albeit, no proceedings have yet been initiated against a manager under the new regime. Managers may be brought to account if they, in the performance of their tasks, intentionally let the undertakings they manage to infringe the prohibition of anticompetitive agreements contained in Article 6 paragraph 1 points 1-6 of the Act or Article 101(1)(a)-(e) TFEU. The need to extend the NCA's sanctioning powers in this manner was identified by commentators (Syp, 2012, p. 15). However, the pervasive feature of this discussion was that policy makers from the very beginning focused not on criminal sanctions as a possible solution, but on administrative fines. Criminalization of competition law enforcement was not considered an alternative way of achieving an equivalent result. Poland did not choose to criminalize competition law enforcement, although this is not the case with all countries in Central and Eastern Europe. Estonia (Svetlicinii, 2014, p. 72-73), the Czech Republic (Pipková and Simeček, 2015, p. 189) and Slovakia (Blažo, 2012, p. 82-83) provide examples of states where the trend has been towards criminalization. However, it is worth noting that Polish proponents of criminal accountability, as an alternative form of managers' accountability, want administrative fines to be just a stop on the way to the criminalization of competition law enforcement (Bernatt and Turno, 2015, p. 88; Sroczyński, 2015a, p. 2). Will the new UOKiK President's sanctioning powers contribute to the effectiveness of competition law enforcement? Despite the fact that fines of up to PLN 2 million (approx. EUR 482,000) seem very deterring, it is questionable whether they give managers a sufficient reason not to engage in a prohibited activity. First, it may be that provisions on

26 See UOKiK President decision of 6.09.2011, DOK-7/2011; UOKiK President decision of 30.12.2010, RGD-31/2010; UOKiK President decision of 12.08.2011, RKT-22/2011; UOKiK President decision of 8.07.2011, RLU-9/2011; UOKiK President decision of 27.09.2010, RLU-16/2010; UOKiK President decision of 16.11.2010, RŁO-34/2010; UOKiK President decision of 31.08.2010, RPZ-20/2010. 
such a severe sanction, if questioned before the Constitutional Tribunal, would be found excessive for what might be regarded as an administrative delict rather than a criminal offence (Skoczny, 2015, p. 176). Second, it seems that administrative fines are not personal enough, and that they may be financed by the manager's undertaking, which enjoyed a profit boost thanks to the managers' prohibited activities.

\section{Leniency program}

The concept of leniency, which originated in the United States ${ }^{27}$ and seems still less prominent in Europe ${ }^{28}$, is an integral part of the Polish legal framework on fines. Amendments to the leniency program are thus going to be considered following the above deliberations on fines. As already mentioned, the leniency program was introduced in Poland as of 1 May 2004. It took shape as a result of works aimed to bring the Polish legal system up to European standards, including the ECN Model Leniency Program. Still, the attitude of the Polish legislature to the tailoring of the conditions of the domestic leniency program has been, however, far from mere fascination with the European model of leniency. Whereas under the EU's leniency program, as well as leniency programs used by the vast majority of Member States ${ }^{29}$, vertical restrictions are considered ineligible for leniency, in Poland leniency is available with respect of both horizontal and vertical agreements (Rumak and Sitarek, 2009, p. 102-103; Kulesza, 2015, p. 94; Molski, 2009, p. 64). Scholars have found this approach to be incompatible with the principles of necessity and of the effective application of Article 101 TFEU (Sitarek, 2014, p. 210). Hence, one might have expected the Amendment Act to become a developmental milestone also with regard to the scope of the applicability of the Polish leniency program, and yet it was not to be. Several other solutions have been changed instead. Unsurprisingly, the amendments have not been inspired by courts. There have been very few published judgments of Polish

27 The contemporary practice of leniency in competition law enforcement is generally considered to have been started by the US Department of Justice in 1978, when it adopted its first Corporate Leniency Policy; see Wils, 2007, p. 213-214.

28 Because whereas in the US the cartel prohibition is enforced not only with fines on undertakings but also with imprisonment of individuals, the Commission and the NCAs of most EU Member States can currently impose fines on undertakings; see Wils, 2007, p. 238-241.

29 See Pipková and Šimeček, 2015, p. 186-192; Neruda, Gachová and Světnický, 2013, p. 161-163. A broad definition of the leniency program, similar to the Polish one and covering also agreements other than cartels, can be found in Sweden; Karlsson and Hansson, 2012, p. 302 . 
courts regarding leniency during, and even after the relevant time-frame ${ }^{30}$; furthermore, they overlooked the drawbacks of the applicable provisions addressed by the Amendment Act. On the other hand, the described package of the improvements to the Polish leniency program can bring benefits to the effectiveness of the program.

First, prior to the Amendment Act, an immunity applicant has had to end its involvement in the alleged agreement no later than on the day of the leniency application. Similarly to the EU, the applicant must do so now immediately following the application, unless the involvement has ceased already. Another aspect in which the Polish leniency program has been brought closer to that of the EU is the scope of the eligibility of undertakings for immunity from fines. In Poland, initiators of agreements and parties which induced others to participate in the agreement were not used to be eligible for immunity from fines, whereas under the EU's program this refers only to undertakings which took steps to coerce other undertakings to join the cartel or to remain in it ${ }^{31}$. The Amendment Act has removed initiators of agreements from the above-mentioned circle of entities. Third, it has added an obligation of the applicant not to disclose the fact of the application without the consent of the UOKiK President. Fourth, the scope of the fine reduction has been amended. Previously, the level of the reduction was relative to the turnover of the applicant. Fines could not exceed $5 \%$ of the turnover of the first beneficiary of a reduction, $7 \%$ of the turnover of the second, and $8 \%$ of the turnover of each subsequent one. The level of the reduction is now relative to the fine which would otherwise be imposed. Similarly to the EU's program, Polish rules provide for a reduction of $30-50 \%$ for the first beneficiary, $20-30 \%$ for the second, and up to $20 \%$ for subsequent ones.

On the other hand, the leniency plus option introduced by the Amendment Act - briefly outlined in this article - signifies the willingness of Polish legislature to accept greater divergence of Polish competition law from the EU model, which does not contain a provision for what is known as leniency plus. It is also worth adding that after the Amendment Act, the Polish leniency program applies to managers. This amendment results from the aforementioned introduction of managers' accountability. However, the new

30 SA judgment of 5.08.2010, VI ACa 116/10; SOKiK judgment of 27.10.2009, XVII AmA 104/08; SN judgment of 24.09.2014, III SK 90/13; SA judgment of 10.05.2013, VI ACa 1362/12; SOKiK judgment of 11.06.2012, XVII AmA 197/10; SN judgment of 3.10.2013, III SK 13/13; SA judgment of 27.06.2012, VI ACa 1339/11; SOKiK judgment of 27.04.2011, XVII AmA 44/09. In the last case, the SN was asked by the applicant to clarify provisions on the latest time to end an involvement in the agreement but the SN refused to answer this question.

31 Commission Notice on immunity from fines and reduction of fines in cartel cases, OJ C 298, 8.12.2006, p. 17-22, at (13). 
provisions on leniency for managers cause new doubts. For instance, it is not completely clear if there is only one common "immunity queue" for both undertakings and managers.

The new leniency plus option means a reduction of $30 \%$ of the fine which would otherwise be imposed on the participant in the first agreement, if such an applicant is the first to disclose a different agreement (Article 113d of the Act). The new provisions give rise to serious doubts about how to interpret them. Not surprisingly, the new provisions on the leniency plus option have not been reported to have been successfully applied yet; instead, they have been the subject of extensive critical commentary (for more see: Martyniszyn and Bernatt, 2015, p. 11; Semeniuk and Syp, 2013, p. 33-41; Skoczny, 2015, p. 172). Much of the debate has focused on the problem of what the notion of the "other agreement" means. Is it an agreement regarding another market, other parties, another period of time, or not necessarily? Second, one may find it hard to explain how to calculate the fine in case the applicant discloses two or more "other agreements".

The introduction of the leniency plus option seems to result from concerns about the effectiveness of competition law enforcement in Poland and is driven by demands for greater access of the NCA to information on anticompetitive agreements, particularly secret cartels and tacit collusions. Where regular leniency has again seemed to fail (only five applications in 2013) ${ }^{32}$, the response has been to introduce a different leniency option, rather than to question why the existing leniency program is at an impasse again. The key point about the choice between introducing the leniency plus option or taking other actions should be that the UOKiK President must be not only a passive recipient of leniency information, but also someone actively seeking to find anticompetitive agreements.

After all, it is worth emphasizing at this point that the recent reform has also covered the introduction of provisions on the protection of leniency documents. They have little in common with the EU model. What marks their divergence from EU law is the fact that they do not give national courts the possibility to conduct the weighing exercise mandated by Pfleiderer ${ }^{33}$ and Donau Chemie ${ }^{34}$ jurisprudence of the Court of Justice of the EU (hereinafter,

32 Over the last decade, Poland had about sixty leniency applications - certainly not a very impressive number. There were several applications per year; only once did the number of applications rise unprecedentedly, from two in 2011 to 16 in 2012. It is also worth noting that there were only two leniency applications in 2015. See: the UOKiK President's reports on activities available at: http://www.uokik.gov.pl/reports_on_activities.php.

33 Pfleiderer AG v. Bundeskartellamt, CJEU judgment of 14.06.2011, C-360/09, ECR [2011] I-05161.

${ }^{34}$ Bundeswettbewerbsbehörde v Donau Chemie AG and others, CJEU judgment of 6.06.2013, C-536/11, ECR [2013] ECLI:EU:C:2013:366. 
CJEU). While working on the Amendment Act, Polish legislature was reluctant to assume obligations that might result from the Pfleiderer and Donau Chemie jurisprudence. Instead, it opted for strengthening the level of protection of leniency documents. Undoubtedly, low level of protection given to leniency documents may endanger the leniency program. Leniency decisions may be followed by actions for damages on the grounds that an undertaking has acknowledged its liability for an infringement. On the other hand, an almost absolute protection of all leniency documents, such as that now granted in Poland, does not fit well with the Pfleiderer and Donau Chemie jurisprudence nor with the newly adopted Damages Directive. That is so even though the latter is "rolling back" Pfleiderer and Donau Chemie to some extent ${ }^{35}$. Polish legislature seems to have paid attention only to one side of the problem of the tensions surrounding the relationship between public and private enforcement. But in the end, it will have to address it once more when transposing the Damages Directive. Notwithstanding the above, it is worth noting that private enforcement of competition law has not gained popularity in Poland so far (Piszcz, 2012, p. 58-76).

\section{Settlements}

Another significant issue relating to fines for anticompetitive practices (anticompetitive agreements and abuses of a dominant position) has been the introduction of a formal settlement procedure. As mentioned in the introduction, the UOKiK President has had the competence to adopt commitment decisions on his own initiative as well as the obligation to accept leniency applications compliant with statutory requirements since 1 May 2004. Despite these developments, there was no tool in-between commitment decisions and leniency under the (2007) Act. Prior to the Amendment Act, this "lacuna" was not at all mentioned by the courts interpreting the (2007) Act.

The Amendment Act introduced the so-called procedure of a voluntary acceptance of a fine (Article 89a of the Act). However, the new rules have not been applied within the first six months after their introduction. The explanatory notes accompanying the Amendment Act call the procedure "settlements", even though the Act does not recognize the possibility of settlement between an authority and a procedural party, as is the case of all Polish administrative

35 Directive of the European Parliament and of the Council 2014/104/EU of 26.11.2014 on certain rules governing actions for damages under national law for infringements of the competition law provisions of the Member States and of the European Union, OJ L 349, 5.12.2014, p. 1-19. See also Pais and Piszcz, 2014, p. 209-234. 
provisions. The assumptions behind the draft Amendment Act, published and submitted for public consultation in $2012^{36}$, declared that the Polish provisions were planned to rely upon the EU's settlement scheme ${ }^{37}$. Even if that was the case, the original ideas have been used outside their context, as explained below.

In the context of EU law, it is typical to view settlements in terms of their procedural qualities, that is, shortening the proceedings and achieving procedural efficiencies (Dekeyser, Becker and Calisti, 2010, p. 684-686; Gheur and Petit, 2009, p. 241-244). Similarly, Member States introduce settlement measures designed to achieve procedural efficiencies ${ }^{38}$. The Polish provisions state that the UOKiK President may, upon request or on his own initiative, invite all parties to the proceedings to engage in the procedure of voluntary acceptance of a fine, provided that the UOKiK President considers that this will facilitate the shortening of the proceedings (Article 89a paragraph 1 of the Act). However, as a rule in Poland, it will be impossible to accelerate proceedings for a number of procedural reasons. First, the procedure may be initiated prior to the completion of proceedings, and the UOKiK President will be obliged to provide proof of the infringement anyway (Kowalik-Bańczyk, 2014a, p. 706; but see Skoczny, 2015, p. 174). Second, the first letter of the UOKiK President and the parties' responses to it declaring if they agree to the proposal or not, are followed by a series of three further letter of the UOKiK President and the parties' responses expected within 14 days (paragraphs 5 and 6) or at least 14 days (paragraph 7). Third, the procedure does not result in the possibility to adopt a streamlined final decision similar to that of the European Commission ${ }^{39}$. Fourth, the procedure does not lead to the restriction of the party's right to access the case file. It seems that the procedure will last many months, while the entire proceedings should last no longer than five months (Article 92 of the Act is of instructive nature). This may give this procedure the reputation of a very time consuming one that leads to the

36 Polish version available at: www.uokik.gov.pl/download.php?plik=11761.

37 The Polish provisions are partly also modeled on the German system (the same level of fine reduction) and the French system (similar scope of coverage, that is, not only cartels but prohibited anticompetitive practices in general). See Krajewska, 2012, p. 59, 63. On the German and French systems see generally Waelbroeck, 2009, p. 242-243.

38 Interestingly, the Czech competition authority used the settlement procedure as a means of procedural economy as well as a means of investigating and proving anticompetitive behavior (together with leniency). The new legal provisions on settlement assign this procedural instrument - in the manner of other European countries - solely to the category of procedural economy; see Pipková and Šimeček, 2015, p. 192-193.

39 Issued in line with the acknowledgements made by the settling companies in their settlement submissions. See Commission Notice on the conduct of settlement procedures in view of the adoption of Decisions pursuant to Article 7 and Article 23 of Council Regulation (EC) No. 1/2003 in cartel cases, OJ C 167, 2.07.2008, p. 1-6. 
extension of proceedings $\mathrm{s}^{40}$. Therefore, one may fear that the procedure could worsen some of the very problems it was meant to resolve.

Differences in the importance of the Polish procedure of a voluntary acceptance of a fine and EU settlement may arise from the fact that while the latter requires an acknowledgement of the parties' liability for the infringement, the Polish procedure does not. The party's position should contain the declaration that the party: (1) submits to a fine voluntarily, (2) confirms the amount of the fine and (3) confirms that the party was: (a) informed of the objections, (b) afforded the opportunity to communicate their views to the UOKiK President, and (c) informed of the consequences of appealing the decision. In return, the UOKiK President grants the party a reduction of the fine by $10 \%$. The Commission specifies the same level of reduction of the fine to the parties ${ }^{41}$.

If the party appeals the decision of the UOKiK President, it will lose the right to the reduction (Article 81 paragraph 3a of the Act); in literature it is more than hinted that this solution may clash with Article 6 of the European Convention on Human Rights and Fundamental Freedoms (Kowalik-Bańczyk, 2014a, p. 706; but see Martyniszyn and Bernatt, 2015, p. 12-13). Article 6(1) ECHR first sentence states that a fair trial within the meaning of the Convention must guarantee for defendants a "fair and public hearing within a reasonable time by an independent and impartial tribunal established by law". At the same time Article 6(2) provides for the presumption of innocence in criminal cases. Article 81 paragraph $3 \mathrm{a}$ of the Act may create concerns regarding whether there is undue pressure on undertakings to settle and not to defend themselves. Procedural parties have a viable alternative to a settlement. It has been suggested in literature relating to EU settlements that the judge should control in all circumstances the final decision particularly where settlements with fines are at stake (Waelbroeck, 2009 , p. 259). The proposal to leave the final decision to the judge should be re-examined in light of procedural justice considerations. However, unlike under EU law, in Poland the scope for such concerns is limited, as the parties retain the right of access to the file and do not have to admit liability. In addition, it is worth noting that while the EU provisions on settlements refer only to cartel cases, Polish provisions cover all anticompetitive practices, including also vertical agreements and abuses of a dominant position ${ }^{42}$. On the other hand, similarly

40 Ibidem.

41 Not all Member States reduce fines as a result of settlements to the same degree. For instance, in the Czech Republic, parties are granted a reduction of the fine of $20 \%$. See Neruda, Gachová and Světnický, 2013, p. 164.

42 The same scheme can be found in the Czech Republic. See Pipková and Šimeček, 2015, p. 193. On the other hand, in Slovakia, the first cases ever to be settled dealt with vertical restraints and the fine reductions imposed reached up to 50\%; see Blažo, 2014, p. 121-122. 
to the EU context, it is entirely up to the UOKiK President as a policy maker if and when to propose the procedure of a voluntary acceptance of a fine. It is up to him and the parties to decide whether they are willing - respectively - to initiate the procedures and to participate therein, as well as to make them work in practice. In this context, it is worth mentioning that both the UOKiK President and a party are allowed to quit the procedure (Article 89a paragraphs 10 and 11 of the Act) (Piszcz, 2015, p. 48). The importance of the new development lies in that it can ultimately contribute to improvements in the enforcement of competition law in Poland, even if it is substantially different to what is being promoted by the European Commission.

\section{Concentrations between undertakings}

The prohibition of anticompetitive practices referred to above is one broad theme. The second, quite separate, but equally important theme is the control of concentrations between undertakings. As to the latter, two different models of proceedings have been generated in Poland. Differences between the previous model and the new one can be summarized in the following lists:

\begin{tabular}{|c|c|}
\hline AS OF 18 JANUARY 2015 & BEFORE 18 JANUARY 2015 \\
\hline - proceedings of up to one month (as a rule) & $\begin{array}{c}\text { proceedings of up to two } \\
\text { months (as a rule) }\end{array}$ \\
\hline $\begin{array}{r}\text { - the UOKiK President's obligation to increase the above } \\
\text { maximum period to five months }(1+4 \text { months) in very } \\
\text { complicated cases, cases where market testing is needed } \\
\text { and cases where a significant impediment to competition } \\
\text { in the market as a result of the concentration is plausible; } \\
\text { the form - an order that is not subject to a complaint }\end{array}$ & - there was no such possibility \\
\hline $\begin{array}{l}\text { in cases where a significant impediment to competition in } \\
\text { the market as a result of thea concentration is plausible, } \\
\text { the UOKiK President presents reasoned "competition } \\
\text { concerns" which can be responded to by the parties within } \\
\text { 14 days (as a rule) }\end{array}$ & - there was no specific legal \\
\hline $\begin{array}{l}\text { time limits for the implementation of commitments are kept } \\
\text { secret by the UOKiK President within those time limits } \\
\text { provided an undertaking makes a request to that effect }\end{array}$ & $-\begin{array}{l}\text { there was no legal basis for } \\
\text { this }\end{array}$ \\
\hline
\end{tabular}

After recent amendments, the Slovak procedure shall be applicable to all competition law infringements including restrictive agreements, abuse of dominance, infringements relating to merger control and other forms of unlawful restrictions of competition; see Šabová, Fodorová and Lukáčová, 2013, p. 230. 
Traditionally, the maximum length of proceedings with respect of a notified concentration was two months. The new system of " 1 plus 4 months" is still not largely oriented on the model established in EU law found in Regulation 139/2004. The major characteristic of the current Polish legal regime is described by certain authors as two-phase proceedings (Wolski, 2013, p. 9; Skoczny, 2015, p. 180). In fact, however, the proceedings appear to be just a shorter and a longer version of the same ${ }^{43}$. Two important arguments have been made in support of the latter position (Dudzik, 2015, p. 30-34). First, various procedural standards do not apply to the different phases; quite the contrary, uniform standards exist for the entire process. In particular, the first part of the proceedings, that is, as a rule the first month, cannot be regarded as a simplified procedure for the treatment of concentrations (which is regulated through soft law in the EU). The explanatory notes accompanying the Amendment Act declared that it would be possible to decide $80 \%$ of the cases within that one month (first phase). If so, then why was the average length of concentration proceedings in Poland 58 days in $2013 ?^{44}$ Shortening the length of proceedings could be achieved in particular by the introduction of a simplified procedure for certain concentrations, yet so far the Polish legislature has been resistant to such a truly far-reaching change. Will the promise of a sharp reduction in the length of proceedings materialize or, quite to the contrary, turn into an overwhelming focus on the search for reasoned causes for the prolongation of proceedings? The heart of the matter seems to rest in the future activities of the UOKiK President.

In parallel, there is a second argument that interested third parties do not have the opportunity to be heard by the UOKiK President neither in the first nor in the second part of merger (concentration) proceedings. This last argument seems to refer to the rhetoric of procedural fairness. The reformers appeared to offer a change in the field of the standards of procedural fairness; however, they focused on its other aspect and it is probable that the underlying motive of the change was not procedural fairness itself but, judging from the explanatory notes accompanying the draft Amendment Act, better communication between the UOKiK President and the parties. Statements of objections were not used in any of the UOKiK President's procedures before the amendment; this makes them not necessarily conform to the need to maintain equality of arms. However, as of 18 January 2015, in cases where a significant impediment to competition in the market as a result

43 On the other hand, two-phase proceedings are a standard not only in case of concentration control by the Commission but also in some Member States, for instance Slovakia; Šabová, Fodorová and Lukáčová, 2013, p. 227.

${ }^{44}$ See: the UOKiK President's reports on activities; available at: http://www.uokik.gov.pl/ reports_on_activities.php. 
of a concentration is plausible, the UOKiK President shall issue so-called "reasoned competition concerns", which can be responded to by the parties within 14 days (as a rule) starting from their receipt. The role and relevance of this kind of statement of objection may be called into question. The essential premise of competition concerns is the same as one of the premises for the prolongation of proceedings. Second, competition concerns cannot be responded to by third parties and participants of the concentration other than parties to the concentration case (notifying parties).

To sum it up, it seems that the Polish legislature might do far more to reform its legal provisions on the control of concentrations than improving communication methods between the UOKiK President and the parties. The legislature was not even encouraged by the opinions of courts to do so. The latter very seldom examined cases based on concentrations of undertakings ${ }^{45}$ since the UOKiK President rarely refused his consent to planned and notified concentrations. As a result, there were very few appeals from his decisions regarding concentrations and courts did not receive a sufficient opportunity to inspire revisions of the provisions on concentrations to be proposed.

\section{Conclusions}

What can be said about these developments in general? The scrutiny of jurisprudence led to the conclusion that irrespective of the importance of the topics discussed by the courts, judges kept as a rule silent on the disadvantages of the (2007) Act, which were later addressed by the reform. The vast majority of judgments can thus not be considered an inspiration for the reformers. A review and legal analysis of the relevant provisions of national and EU laws show that, after the recent Polish reforms, both the EU and Poland remain divergent on a number of key issues in terms of the enforcement of competition rules. They include the design of remedies, fines and periodic penalty payments, leniency plus and settlements as well as merger (concentration) proceedings. In the case of the latter, one may regret that the work of the Polish legislature seemed to be a matter of running quite fast in order to stay almost in the same place. The reform of the domestic merger control regime would have been more successful if it derived more inspirations from EU law. In a few instances, legislators have declared that they drew inspiration from provisions of EU law, but it is noticeable that the

45 SA judgment of 13.10.2011, VI ACa 381/11; SOKiK judgment of 29.10.2009, XVII AmA 153/09; SOKiK judgment of 9.08.2010, XVII AmA 83/09; SOKiK judgment of 5.04.2011, XVII AmA 213/09; SOKiK judgment of 13.04.2011, XVII AmA 78/09. 
final result ultimately embodied in Polish legal provisions contradicts what is known in the EU by the very conception of a given legal phenomenon (as in the case of settlements).

Yet, in all their diversity, these provisions do still possess a certain resemblance. As has been observed above, in some respects the recent developments in Poland have tended toward greater convergence with the European model (for example, the regular leniency program). Several of the presented developments (provisions on remedies and fines) seem to reflect a determination of the Polish legislature to subject undertakings, associations of undertakings and managers to increased discipline, irrespective of whether these changes are regarded as convergent or divergent with the EU model. The general revision of the Act has been neither comprehensive nor systemic. This is one of the central arguments for launching further legislative works regarding the enforcement of competition law in Poland. In the course of these works legislators should remember that both copying the EU (convergence) and developing a separate Polish model (divergence) would provide a bundle of gains and losses. Legislative works should thus be accompanied by careful scrutiny of the proposals with respect to both their pro-EU aspects and their prospective effectiveness.

To some extent, national competition laws undergo a spontaneous (soft) harmonization without any formal obligations being placed on Member States in that respect. In particular, there is no duty to refer to procedural acquis in purely internal situations (see Kowalik-Bańczyk, 2014b, p. 145-151). In any event, there seems to be no reason why - subject to Article 3 of Regulation 1/2003 and except for those instances where the obligation of implementing EU law is placed on Poland as a member state - Polish provisions should be spontaneously adapted to less effective EU rules. Fines imposed on parties with a low turnover can be used as an example here. The new Polish provisions cannot be considered perfect, and yet the Polish legal framework can be deemed more effective than its EU counterpart. This may well prove to be one of the most valuable lessons to be learnt by the EU from Poland's development of its legal framework.

\section{Literature}

Bernatt, M. and Turno, B. (2015). O potrzebie doskonalenia rozwiązań procesowych w znowelizowanej z dniem 18 stycznia 2015 r. ustawie o ochronie konkurencji i konsumentów. internetowy Kwartalnik Antymonopolowy i Regulacyjny, 2, 75-92.

Blažo, O. (2012). What Do Limitation Periods for Sanctions in Antitrust Matters Really Limit? Yearbook of Antitrust and Regulatory Studies, 5(7), 79-103. 
Blažo, O. (2014). Twenty Years of Harmonisation and Still Divergent: Development of Slovak Competition Law. Yearbook of Antitrust and Regulatory Studies, 7(9), 109-123.

Cseres, K.J. (2014). Accession to the EU's Competition Law Regime: A Law and Governance Approach. Yearbook of Antitrust and Regulatory Studies, 7(9), 31-66.

Dekeyser, K., Becker, R. and Calisti, D. (2010). Impact of public enforcement on antitrust damages actions: Some Likely Effects of Settlements and Commitments on Private Actions for Damages. In: C.-D. Ehlermann, M. Marquis (eds), European Competition Law Annual 2008: Antitrust Settlements under EC Competition Law. Oxford and Portland Oregon: Hart Publishing.

Doniec, A. (2015). Stosowanie kar pieniężnych $w$ unijnym i polskim prawie konkurencji $w$ świetle wymogów ochrony praw człowieka. Warszawa: Wydawnictwo Naukowe Wydziału Zarządzania Uniwersytetu Warszawskiego.

Dudzik, S. (2015). Kontrola koncentracji w świetle ostatnich zmian ustawowych. internetowy Kwartalnik Antymonopolowy i Regulacyjny, 2, 27-41.

Jurkowska-Gomułka, A. (2014). Art. 10. In: T. Skoczny (ed.), Ustawa o ochronie konkurencji $i$ konsumentów. Komentarz. Warszawa: Wydawnictwo C.H. Beck.

Karlsson, K. and Hansson, P. (2012). Sweden. In: J. Buhart (ed.), Leniency Regimes: Jurisdictional Comparisons. London: Sweet \& Maxwell.

Kowalik-Bańczyk, K. (2014a). Reforms of Polish Antitrust Law: Closer to, or Further From, the European Model? Journal of European Competition Law \& Practice, 5(10), 703-710.

Kowalik-Bańczyk, K. (2014b). Ways of Harmonising Polish Competition Law with the Competition Law of the EU. Yearbook of Antitrust and Regulatory Studies, 7(9), 141-159.

Krajewska, E. (2012). Settlement w świetle doświadczeń europejskich - w poszukiwaniu najlepszych rozwiązań. internetowy Kwartalnik Antymonopolowy i Regulacyjny, 4, 57-76.

Król-Bogomilska, M. (2001). Kary pieniężne $w$ prawie antymonopolowym. Warszawa: KiK Konieczny i Kruszewski.

Król-Bogomilska, M. (2012). Standards of Entrepreneur Rights in Competition Proceedings - a Matter of Administrative or Criminal Law? Yearbook of Antitrust and Regulatory Studies, 5(6).

Kulesza, M. (2015). Leniency - the Polish Programme and the 'Semi-formal' Harmonisation in the EU by the European Competition Network. Yearbook of Antitrust and Regulatory Studies, 8(11), 83-100.

Martyniszyn, M. and Bernatt, M. (2015). On Convergence with Hiccups: Recent amendments to Poland's Competition Law. European Competition Law Review, 1, 8-14.

Molski, R. (2009). Polish Antitrust Law in its Fight Against Cartels - Awaiting a Breakthrough. Yearbook of Antitrust and Regulatory Studies, 2(2), 49-76.

Neruda, R., Gachová, L. and Světnický, R. (2013). 9th Amendment to the Czech Competition Act. Yearbook of Antitrust and Regulatory Studies, 6(8), p. 159-172.

Pais, S.O. and Piszcz, A. (2014). Package on Actions for Damages Based on Breaches of EU Competition Rules: Can One Size Fit All? Yearbook of Antitrust and Regulatory Studies, 7(10), 209-234.

Pipková, P.J. and Šimeček, I. (2015). New Procedural Notices of the Czech Office for the Protection of Competition: Leniency, Settlement, and Alternative Problem Resolution. Yearbook of Antitrust and Regulatory Studies, 8(11), 185-203. 
Piszcz, A. (2012). Still-unpopular Sanctions: Developments in Private Antitrust Enforcement in Poland After the 2008 White Paper. Yearbook of Antitrust and Regulatory Studies, 5(7), $58-76$.

Piszcz, A. (2013). Sankcje w polskim prawie antymonopolowym. Białystok: Wydawnictwo Temida2.

Piszcz, A. (2015). Nowe elementy regulacji prawnej kar pieniężnych w ustawie o ochronie konkurencji i konsumentów. internetowy Kwartalnik Antymonopolowy i Regulacyjny, 2.

Rumak, E. and Sitarek, P. (2009). Polish Leniency Programme and its Intersection with Private Enforcement of Competition Law. Yearbook of Antitrust and Regulatory Studies, 2(2), 99-123.

Šabová, Z., Fodorová, K. and Lukáčová, D. (2013). Recent Developments in Slovak Competition Law - Legislation and Case Law Review. Yearbook of Antitrust and Regulatory Studies, 6(8), 223-243.

Semeniuk, P. and Syp, S. (2013). „Wylanie dziecka z kąpielą” - czyli o leniency plus w Polsce. internetowy Kwartalnik Antymonopolowy i Regulacyjny, 7, 31-41.

Sitarek, P. (2014). The Impact of EU Law on a National Competition Authority's Leniency Programme - the Case of Poland. Yearbook of Antitrust and Regulatory Studies, 7(9), $185-216$.

Skoczny, T. (2015). 2014 Amendment of the Polish Competition and Consumers Protection Act 2007. Yearbook of Antitrust and Regulatory Studies, 8(11), 165-183.

Sroczyński, J. (2015a). O potrzebie (i pułapkach) 'bardziej interdyscyplinarnego podejścia' do publicznego i prywatnego prawa konkurencji. Paper presented at the 1 Polish Congress for Competition Law, Warszawa, 13-15 April.

Sroczyński, J. (2015b). Tzw. środki zaradcze (remedies) w znowelizowanej ustawie antymonopolowej: istotny wzrost uprawnień Prezesa UOKiK. Przegląd Ustawodawstwa Gospodarczego, 2, IX-XIX, at XIII.

Svetlicinii, A. (2014). Enforcement of EU Competition Rules in Estonia: Substantive Convergence and Procedural Divergence. Yearbook of Antitrust and Regulatory Studies, 7(9), 67-85.

Syp, S. (2012). O odpowiedzialności osób fizycznych w polskim prawie konkurencji - de lege lata i de lege ferenda. internetowy Kwartalnik Antymonopolowy i Regulacyjny, 4, 17-19.

Waelbroeck, D. (2009). The development of a new 'settlement culture' in competition cases. In: C. Gheur, N. Petit (eds), Alternative enforcement techniques in EC competition law: Settlements, commitments and other novel instruments. Bruxelles: Bruylant.

Wils, W.P.J. (2007). Leniency in Antitrust Enforcement: Theory and Practice. In: D. Schmidtchen, M. Albert, S. Voigt (eds), The More Economic Approach to European Competition Law. Tübingen: Mohr Siebeck.

Wolski, D. (2013). Kierunek zmian w zakresie kontroli koncentracji przedsiębiorców w projekcie nowelizacji ustawy o ochronie konkurencji i konsumentów. internetowy Kwartalnik Antymonopolowy i Regulacyjny, 1, 8-16. 